\title{
Bacterial colonization and microbial decomposition of limnetic organic aggregates (lake snow)
}

\author{
Hans-Peter Grossart ${ }^{*}$, Meinhard Simon \\ Limnological Institute, University of Konstanz, PO Box 5560, D-78434 Konstanz, Germany
}

\begin{abstract}
We studied the composition, microbial colonization and organic matter fluxes of lake snow in Lake Constance, Germany, in 1993. Aggregates were collected between 6 and $25 \mathrm{~m}$ by SCUBA or made in the lab in rolling cylinders from samples from the epilimnion. Aggregates were composed of living and senescent phytoplankton, zooplankton molts and carcasses, and other unidentifiable debris. Dry weight and particulate organic carbon (POC) were 3 to $20 \mu \mathrm{ggg}^{-1}$ and 1.5 to $33 \mu \mathrm{g} \mathrm{C} \mathrm{agg}^{-1}$, respectively. Carbon in particulate combined amino acids (PCAA) was 8 to $51 \%$ of POC on aggregates but only $<10 \%$ in bulk POC. Aggregates were densely colonized, with 5 to $80 \times 10^{6}$ bacteria agg $^{-1}$, and numbers usually increased with depth. Production and growth rates of bacteria on aggregates (aggregate bacteria) were low compared to free-living bacteria. However, the organic matter turnover within the aggregates and release into the surrounding water were high due to intense activities of the ectohydrolases (aminopeptidase, alkaline phosphatase, $\alpha$ - and $\beta$-glucosidase, and chitinase) of aggregate bacteria. Activities of the aminopeptidase were consistently higher than those of the other enzymes. In laboratory experiments dissolved amino acids, mainly DCAA, were released from aggregates into the surrounding water; turnover times of PCAA on aggregates due to hydrolysate release usually ranged from $<5$ to $25 \mathrm{~h}$. Lake snow thus was a potential source of amino acids for free-living bacteria in the epiand hypolimnion of Lake Constance. The colonization of lab-made aggregates showed a transition from small to large rods within the first 2 to $5 \mathrm{~d}$ after aggregation to filamentous, grazing-resistant bacteria. This community was largely composed of microbes of the domain Bacteria, determined by in situ hybridization with rRNA-targeted fluorescent oligonucleotide probes. $\beta$-Proteobacteria were usually dominant, particularly in aged aggregates. At earlier stages $\alpha$-Proteobacteria also comprised substantial fractions of the community. This community structure is similar to that of activated sludge flocs, suggesting that lake snow has a function in lacustrine ecosystems comparable to that of activated sludge flocs in sewage treatment plants.
\end{abstract}

KEY WORDS: Lake snow - Bacteria POM - Amino acids In situ hybridization - Ectoenzyme activities . Lake Constance

\section{INTRODUCTION}

Macroscopic organic aggregates, $\geq 3 \mathrm{~mm}$ in diameter, both in marine and limnetic environments are known as colonization sites of a rich and diverse community of autotrophic and heterotrophic microorganisms. In general, algae, bacteria, flagellates, and cili-

\footnotetext{
- Present address: Institute for Chemistry and Biology of the Marine Environment, PO Box 2503, D-26111 Oldenburg, Cermany. E-mail: hgrossart@icbm.uni-oldenburg.de
}

ates inhabit marine snow as well as lake snow at concentrations much higher than those found in the surrounding water (Shanks \& Trent 1979, Caron et al. 1986, Alldredge \& Silver 1988, Grossart \& Simon 1993). Enhanced concentrations of organic matter and nutrients on marine snow (Shanks \& Trent 1979, Gotschalk \& Alldredge 1989, Herndl 1992) indicate that it is an important microhabitat for organic matter decomposition and nutrient recycling in the water column.

The role of marine snow in the rapid transformation of particulate organic matter (POM) in the pelagic zone has been shown by several studies (Alldredge \& 
Gotschalk 1990, Kaltenböck \& Herndl 1992, Smith et al. 1992). Cho \& Azam (1988) were first to argue that particle-attached bacteria must transform the particulate into the dissolved phase to support their measured production rates of free-living bacteria. Measurements of hydrolytic ectoenzyme activities of particle-associated and free-living bacteria have shown that bacteria on particles hydrolyze more organic matter than they take up (Hoppe 1991, Smith et al. 1992); thus, organic aggregates are hotspots of POM solubilization to DOM (dissolved organic matter) in the pelagic zone.

High metabolic activity and respiration of aggregate-associated microorganisms (Paerl \& Prufert 1987) may lead to anoxic microzones (Alldredge \& Cohen 1987, Shanks \& Reeder 1993). As a result, large aggregates may support anaerobic processes, e.g. methanogenesis, in the aerobic bulk water (Bianchi et al. 1992). The significance of aggregates as microenvironments distinct from the surrounding water is reflected by changes of their microbial community in hours to days (Alldredge \& Silver 1988), and in community structures different from the surrounding water (DeLong et al. 1993, Weiss et al. 1996).

We investigated bacterial colonization and decomposition of lake snow in Lake Constance, Germany, to test the hypothesis that lake snow, like marine snow, acts as hotspots of enhanced microbial decomposition of POM and thus provides an important source of DOM in the pelagic zone. In addition, we followed the bacterial community structure on lake snow in time to test if it changes during aggregate aging.

\section{MATERIAL AND METHODS}

This study was conducted in the Überlinger See, northwestern Lake Constance $\left(47^{\circ} 40^{\prime} \mathrm{N}, 9^{\circ} 15^{\prime} \mathrm{E}\right)$ at a central station (max. depth $=147 \mathrm{~m}$ ). Water samples were collected at 6 depths $(3,6,10,15,25$, and $50 \mathrm{~m})$ from late March to mid-November 1993. Lake snow was enumerated and collected in situ at 6,15 , and $25 \mathrm{~m}$ depth, as in Grossart et al. (1997). The morphology and composition of lake snow were studied microscopically. Aggregates were prepared for scanning electron microscopy (SEM; Zeiss DSM 950) using the protocol of Paerl (1974). Dry weight (DW), particulate organic carbon (POC), and CHN of total seston and aggregates were measured after filtration through glass microfibre filters ( $1 \mu \mathrm{m}$ pore size; Schleicher \& Schüll, Germany). The filters were dried at $110^{\circ} \mathrm{C}$ for $1 \mathrm{~h}$ to determine DW POC and CHN content were measured by CHN analysis (Carlo Erba, Italy). For further details see Grossart \& Simon (1998, in this issue).

Dissolved free (DFAA) and combined (DCAA) amino acids were determined by high performance liquid chromatography (HPLC) after precolumn derivatization with o-phthaldialdehyde according to Simon \& Rosenstock (1992). Samples were prefiltered through $0.2 \mu \mathrm{m}$ tuffrin filters (Gelman Acrodisc; low protein binding capacity). DFAA were measured directly. Samples of DCAA and particulate combined amino acids (PCAA) were hydrolyzed prior to analysis in double-distilled $6 \mathrm{~N} \mathrm{HCl}$ for $20 \mathrm{~h}$ at $110^{\circ} \mathrm{C}$. Amino acid oxidation due to high nitrate concentrations was prevented by adding $20 \mu \mathrm{l}$ of ascorbic acid $(2 \mathrm{mg}$ $\mathrm{ml}^{-1}$ ) prior to hydrolysis. Concentrations of DCAA and PCAA in moles were calculated as amino acid equivalents.

Free-living and aggregate bacteria were counted after DAPI staining by epifluorescence microscopy (Porter \& Feig 1980, Grossart \& Simon 1998). Bacterial biomass was calculated from cell numbers and an annual mean cell volume of $0.053 \mu^{3}$ for free-living

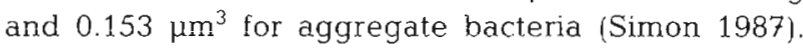
Bacterial protein was calculated according to Simon \& Azam (1989) and resulted in $19 \mathrm{fg}$ protein per freeliving cell and $53 \mathrm{fg}$ protein per cell on aggregates.

Bacterial colonization was examined on lab-made aggregates formed in rolling plexiglass cylinders (1.4 l) at $2.5 \mathrm{rpm}$ (Shanks \& Edmondson 1989) during the course of $12 \mathrm{~d}$. Water for these experiments was collected at $6 \mathrm{~m}$ depth and incubated in the cylinders at in situ temperature in a 12:12 h light:dark cycle. Five experiments were performed: Expts 1 and 2 on $17 \mathrm{Au}$ gust and 16 October 1992, respectively; Expts 3, 4, and 5 on 9 February, 4 May, and 13 August 1993, respectively. Expt 3 was run at $15^{\circ} \mathrm{C}$ and not at the ambient temperature of $4^{\circ} \mathrm{C}$. Numbers, form, and size of bacteria were monitored by epifluorescence and SEM.

Colonization and community structure of aggregate bacteria were examined by in situ hybridization with rRNA-targeted fluorescent oligonucleotide probes according to Weiss et al. (1996). Aliquots $(29 \mu \mathrm{l})$ of sonicated aggregates were pipetted onto gelatin-coated teflon microslides ( $P$. Marienfeld KG, Bad Mergentheim, Germany) and dried at $46^{\circ} \mathrm{C}$. The samples were fixed in $40 \mu \mathrm{l}$ of freshly prepared $4 \%$ paraformaldehyde for $4 \mathrm{~h}$ at $4^{\circ} \mathrm{C}$. Oligonucleotide probes specific for Bacteria (EUB 338; Amann et al. 1990) and for the $\alpha$-, $\beta$ - and $\gamma$-subclasses of Proteobacteria (ALF $1 \mathrm{~b}, \mathrm{BET} 42$ a, and GAM 42a; Manz et al. 1992) were used.

Anaerobic microzones in the aggregates were characterized by the reduction of 2,3,5-triphenyl-3-tetrazoliumchloride (TTC; Sigma) to microscopically visible crystals of formazan (Paerl \& Prufert 1987). TTC was added to the samples at $0.01 \%$ (wt/vol) and incubated for $3 \mathrm{~h}$ in the dark. Samples were fixed with neutralized borate-buffered glutaraldehyde (3\% final conc.) and stored at $4{ }^{\circ} \mathrm{C}$ until the microscopic analysis. Respiring bacteria were determined after incubation with 
5-cyano-2,3-ditolyl-tetrazoliumchloride (CTC; Polyscience-Inc.) according to Schaule et al. (1993) but modified in that we did not add peptone prior to incubation. Samples were incubated with CTC at $5 \mathrm{mM}$ for $1 \mathrm{~h}$ in the dark, fixed with $2 \%$ formalin, and stored at $4^{\circ} \mathrm{C}$ until further analysis. Using the dual-staining approach with DAPI the total numbers and respiring bacteria were determined simultaneously by epifluorescence microscopy.

Hydrolytic ectoenzyme activities of free-living and aggregate bacteria were measured with fluorogenic substrate analogs (Hoppe 1993). The substrates used were L-leucine-methyl coumarinylamide (MCA, aminopeptidase), methyl umbelliferyl- $\alpha$ - and $\beta$-D-glucoside (MUF, $\alpha$ - and $\beta$-glucosidase), MUF- $N$-acetyl $\beta$ glucoside ( $N$-acetyl $\beta$-glucosidase), and MUF-phosphate (alkaline phosphatase). To measure hydrolysis by free-living bacteria, samples of $5 \mathrm{ml}$ were incubated with substrates at $50 \mu \mathrm{M}$ (final conc.) for $1 \mathrm{~h}$ at in situ temperature in the dark. Hydrolysis rates of aggregate bacteria were measured by pooling 10 aggregates in $5 \mathrm{ml}$ of surrounding water and adding substrates at 250 to $500 \mu \mathrm{M}$ (final conc.). Incubation was as for freeliving bacteria. Added substrate concentrations assured maximum hydrolysis rates as determined by concentration kinetics. All samples were run in triplicate with 1 heat-killed control $\left(80^{\circ} \mathrm{C}\right.$ for $\left.20 \mathrm{~min}\right)$. Fluorescence was read at $380 \mathrm{~nm}$ excitation and $440 \mathrm{~nm}$ emission for MUF substrates or $365 \mathrm{~nm}$ excitation and $455 \mathrm{~nm}$ for MCA substrates using a Kontron SFM 25 fluorometer. The activity of aggregate bacteria was calculated as total activity minus that of free-living bacteria.

Bacterial production was measured by using a duallabel approach (Chin-Leo \& Kirchman 1988) of ${ }^{3} \mathrm{H}$ thymidine (TdR; Fuhrman \& Azam 1980) and $\left[{ }^{14} \mathrm{C}\right.$ leucine incorporation (Leu; Kirchman et al. 1985, Simon \& Azam 1989) into the ice-cold trichloroacetic acid precipitate. TdR (75 $\mathrm{Ci} \mathrm{mmol}{ }^{-1}$ ) and Leu $(312 \mathrm{mCi}$ $\mathrm{mmol}^{-1}$, both from Amersham) were added to triplicate samples and a formalin-killed control and incubated for $1 \mathrm{~h}$. For free-living bacteria the protocol of Simon \& Rosenstock (1992) was applied using $30 \mathrm{nM}$ of each label (final conc.), whereas for aggregate bacteria 10 aggregates were pooled in $5 \mathrm{ml}$ of surrounding water and incubated at a final concentration of $60 \mathrm{nM}$ of $\mathrm{TdR}$ and Leu. For further details see Grossart \& Simon (1993).

The release of DFAA and DCAA from the aggregates into the surrounding water was measured by incubating 10 natural or 2 lab-made aggregates in $30 \mathrm{ml}$ glass syringes filled with $0.2 \mu \mathrm{m}$ prefiltered lake water. Three experiments with natural aggregates were performed (Expt 1 on 16 October 1992, Expts 2 and 3 on 3 and 10 April 1993, respectively) and 1 with lab-made aggregates (Expt 4 on 23 January 1991). Each experiment was run in triplicate such that the syringes were rotated vertically at $2.5 \mathrm{rpm}$ and incubated under the same conditions as the plexiglass cylinders (see above). Subsamples of surrounding water were withdrawn periodically through a 3-way valve at the tip of the syringes for subsequent DFAA and DCAA analysis by HPLC (see above). The net release of dissolved amino acids was calculated as the increase of their concentration in the surrounding water over time.

\section{RESULTS}

\section{Abundance, type, and composition of lake snow}

Abundances of lake snow in 1993 were $<1$ to $50 \mathrm{l}^{-1}$. Maximum numbers occurred in the phytoplankton spring bloom, during the clear water phase, the phytoplankton bloom in summer and fall. Aggregates were $<3$ to $20 \mathrm{~mm}$ in diameter and on average $5.5 \mathrm{~mm}$, equivalent to a spherical volume of $87 \mu^{3}$ agg. $^{-1}$. Small comet-shaped aggregates were found at the end of the phytoplankton spring bloom when small diatoms were present. The largest aggregates were formed by large diatoms and filamentous green algae after strong wind events at the beginning of the summer bloom. For further details see Grossart et al. (1997) and Grossart \& Simon (1998). A special type of aggregated material occurred at the end of March as a dense surface film of diatoms and detritus.

The dry weight of lake snow was 3 to $120 \mu \mathrm{ggg.}^{-1}$ and the POC content 1.5 to $33 \mu \mathrm{gagg}^{-1}$ (Table 1 ). The

Table 1. Type, dry weight, and POC per aggregate collected at various depths. Mean values of 10 aggregates pooled for the measurements are given

\begin{tabular}{|llccc|}
\hline Date & $\begin{array}{l}\text { Type of } \\
\text { aggregate }\end{array}$ & $\begin{array}{c}\text { Depth } \\
(\mathrm{m})\end{array}$ & $\begin{array}{c}\text { Dry weight } \\
\left(\mu \mathrm{agg}^{-1}\right)\end{array}$ & $\begin{array}{c}\text { POC } \\
\left(\mu \mathrm{agg}^{-1}\right)\end{array}$ \\
\hline 24 Apr & Small diatoms & 15 & 3 & 1.5 \\
& & 25 & 3.8 & 1.9 \\
$10 \mathrm{May}$ & Molts of daphnids & 15 & 10 & 2.8 \\
$26 \mathrm{May}$ & Molts and car- & 15 & 20 & 3.5 \\
& casses of daphnids & 25 & 17 & 3.0 \\
31 May & Large diatoms & 15 & 3 & 1.7 \\
& & 25 & 30 & 8.5 \\
22 Jul & Large diatoms & 6 & 120 & 33.0 \\
& & 15 & 25 & 8.5 \\
16 Aug & Miscellaneous & 25 & 22 & 6.2 \\
23 Aug & Miscellaneous & 15 & 23 & 3.0 \\
& & 25 & 9 & 6.5 \\
11 Oct & Cyanobacteria & 6 & 3 & 2.2 \\
& & & & \\
\hline
\end{tabular}




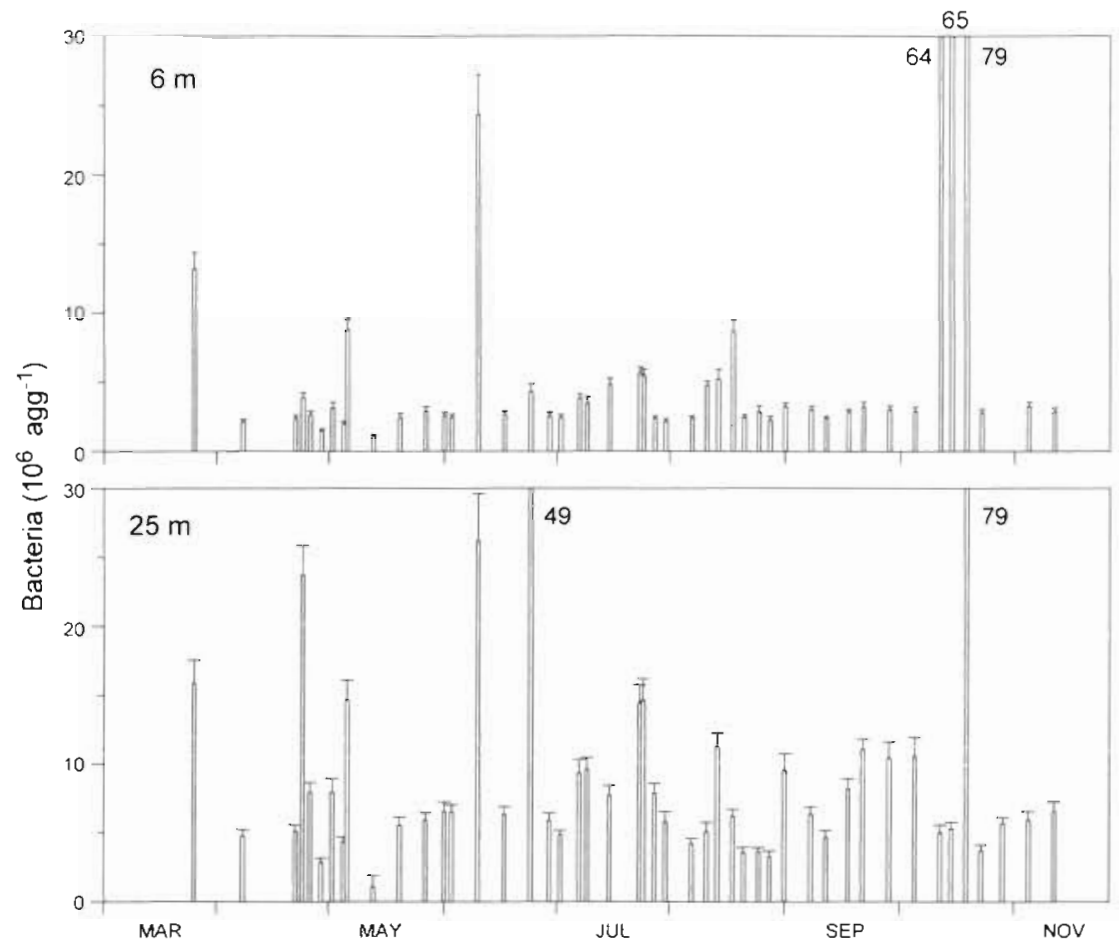

Fig. 1 Bacterial numbers on lake snow collected at 6 and $25 \mathrm{~m}$ depth from March until November 1993 in Lake Constance
Higher numbers on lake snow were also recorded towards the end of the spring bloom, whereas in summer large diatom aggregates were sparsely colonized. In spite of their high numbers, aggregate bacteria comprised only a small fraction of total planktonic bacteria $(\leq 4.3 \%)$. However, because aggregate bacteria were, on average, $3 \times$ larger than the freeliving bacteria, they represented a larger fraction of the total bacterial biomass $(\leq 13 \%)$.

More than $60 \%$ of aggregate bacteria were respiring, in dense accumulations even 90\%, irrespective of the type of aggregate. In contrast, only 6 to $10 \%$ of the free-living bacteria were detected by CTC as respiring cells.

Bacterial protein production expressed as carbon (BPP-C) was $<0.1$ to $1.08 \mathrm{ng} \mathrm{C}$ agg. $^{-1} \mathrm{~h}^{-1}$, excluding the surface film at the end of March. It usually increased with depth (Fig, 2). Highest BPP-C highest values were found on aggregates composed of large diatoms and low values on those composed of small diatoms, single crustacean molts, or cyanobacteria. Large aggregates which consisted of diatoms and filamentous green algae at all depths often exhibited anaerobic microzones, indicating high respiratory activities of their microbial community. Anaerobic microzones were less frequent on lake snow of small diatoms in spring and on molts of zooplankton in the clear water phase.

\section{Numbers and activities of lake-snow- associated bacteria}

Bacterial abundance on aggregates ranged from 5 to $80 \times 10^{6}$ rells ang ${ }^{-1}$ (Fig. 1). In general, it increased with depth, as reflected by the mean values $\left(4.04 \pm 3.88 \times 10^{6}\right.$ cells agg. ${ }^{-1}$ at $6 \mathrm{~m}$ and $8.77 \pm 7.83 \times 10^{6}$ cells agg $^{-1}$ at $25 \mathrm{~m}$ excluding cyanobacterial aggregates in October). The highest numbers occurred on zooplankton-derived aggregates at the end of June at $25 \mathrm{~m}$ and on cyanobacterial aggregates at the end of the bloom in October at 6 and $25 \mathrm{~m}$.

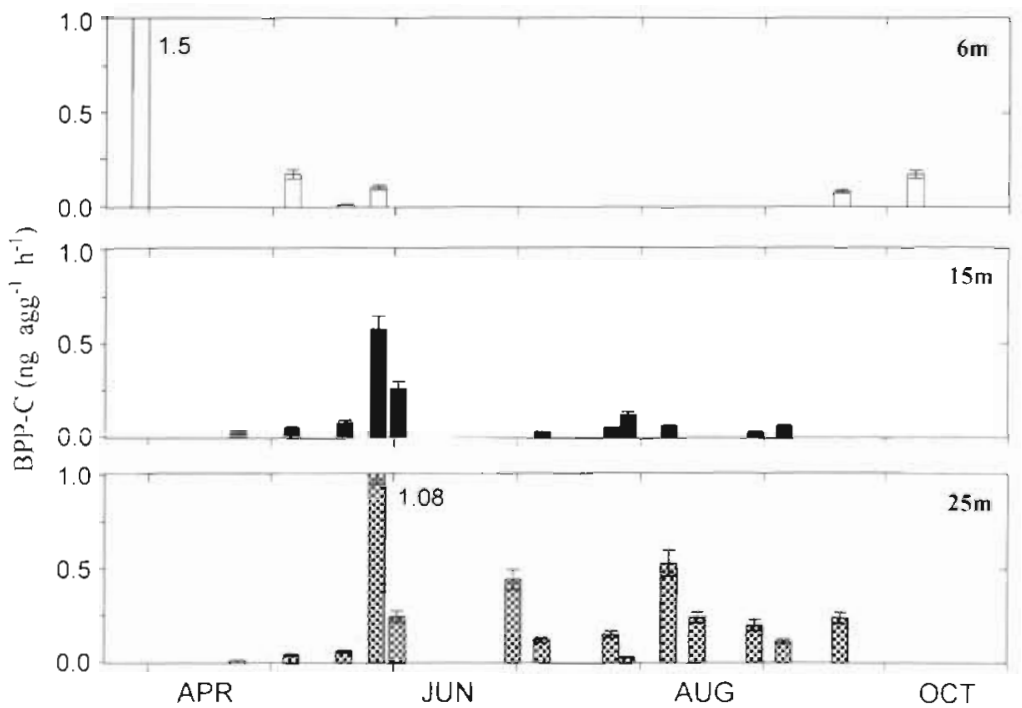

Fig. 2. Bacterial protein production (BPP-C) determined by ${ }^{14} \mathrm{C}$-leucine incorporation on lake snow collected at 6,15 , and $25 \mathrm{~m}$ depth in Lake Constance in 1993 
Fig. 3. Concentration of particulate combined amino acids (PCAA) on lake snow collected at 6,15 , and $25 \mathrm{~m}$ depth in Lake Constance in 1993

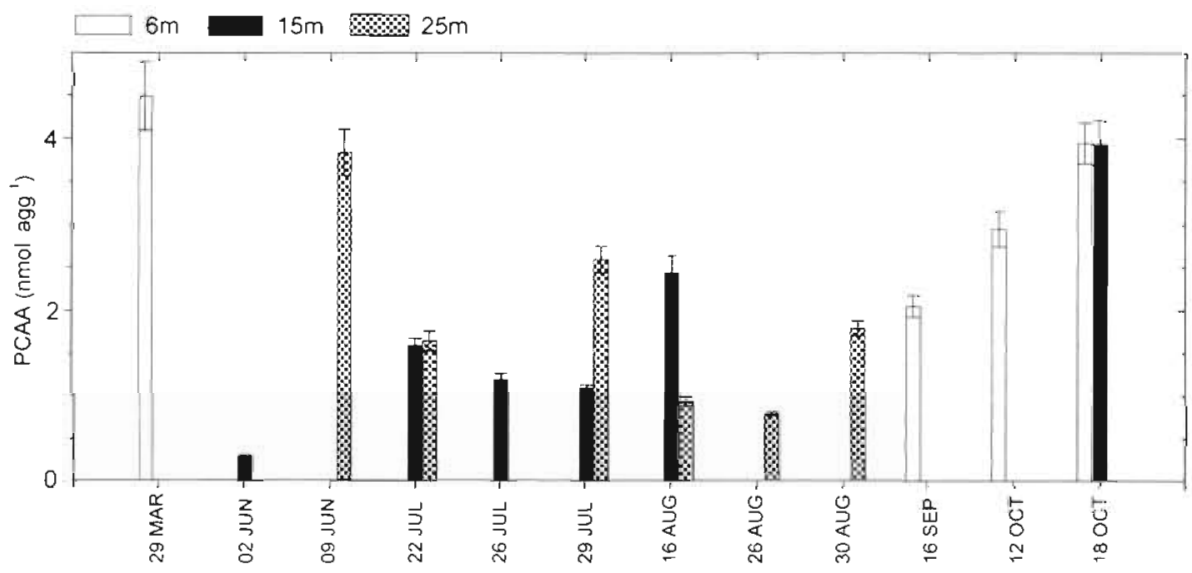

rates in the surrounding water decreased with depth. The direct comparison of BPP-C rates on aggregates with those in the surrounding water showed that $<1$ to $13.9 \%$ of total BPP-C was on lake snow. Highest percentages occurred when BPP-C rates in the surrounding water were lowest. Percentages of BPP-C did not covary with those of bacterial numbers both on aggregates and in the surrounding water.

Growth rates of aggregate bacteria calculated on the basis of $\mathrm{TdR}$ incorporation and bacterial numbers ranged between 0.01 and $0.09 \mathrm{~d}^{-1}$. These rates were up to 10 times lower than those of free-living bacteria and only at the end of May and in early August were they similar to or higher than in the surrounding water. In general, the seasonal pattern followed that of BPP-C.

\section{Concentrations of particulate combined amino acids (PCAA)}

Concentrations of PCAA were 1.2 to $3.9 \mathrm{nmol}$ agg. ${ }^{-1}$, excluding the surface film at the end of March. Highest values were found on large aggregates at the beginning of June (filamentous green algae) and on aggregates in mid-October (cyanobacteria; Fig. 3). The C:N ratio of PCAA on lake snow was 3.4 to 5.5 (Grossart \& Simon 1998) with a mean of 4.5 . In contrast, the C:N ratio of PCAA of suspended POM $\leq 100 \mu \mathrm{m}$ was lower, with a mean of 3.5 . This difference in amino acid composition is due to high percentages of aspartate, glutamate, and serine and low percentages of valine, isoleucine, and leucine on lake snow as compared to suspended POM.

Total concentrations of aggregate-associated PCAA were 0.02 to $0.16 \mu \mathrm{M}$ and concentrations of bulk PCAA $\leq 0.042$ to $3.16 \mu \mathrm{M}$. In spring and during the clear water phase, PCAA on lake snow as percent of bulk PCAA was low $(<10 \%)$, whereas it comprised 40 to $60 \%$ at the beginning of the summer bloom when aggregates were highly abundant ( $>10$ agg. $1^{-1}$ ). PCAA on cyanobacterial aggregates in fall comprised $\geq 30 \%$ of total PCAA.

PCAA on aggregates comprised 18 to $270 \mathrm{ng} \mathrm{C}$ agg. ${ }^{-1}$, assuming an average formula weight of amino acids of 120 and $\mathrm{C}$ as $50 \%$ of the formula. PCAA-C was 8 to $51 \%$ of lake-snow-associated POC (Grossart \& Simon 1998 ) and only $\leq 10 \%$ on suspended $P O C \leq 100 \mu m$. The bacterial biomass on aggregates was $\leq 57$ to $2175 \mathrm{ng} \mathrm{C}$ agg. ${ }^{-1}$, which is generally higher than PCAA-C agg. ${ }^{-1}$. Only on the surface film of diatoms did bacterial biomass comprise $10.6 \%$ of PCAA-C. In contrast, on cyanobacterial lake snow it was up to $6 \times$ higher than PCAA-C. Taking into account the error in the measurements of PCAA and bacterial biomass on aggregates, this calculation indicates that bacteria are a major component of proteins on aggregates.

\section{Concentrations of dissolved free (DFAA) and combined (DCAA) amino acids}

Concentrations of DFAA and DCAA in the matrix water of lake snow were 0.15 to $0.72 \mu \mathrm{M}$ and 2.3 to $49.9 \mu \mathrm{M}$, respectively (Table 2). Extremely high concentrations of DFAA $(1.79 \mu \mathrm{M})$ and DCAA $(46 \mu \mathrm{M})$ were found in the diatom surface film in early spring. DFAA and DCAA concentrations in the matrix water were substantially higher than in the surrounding water (Table 2). DCAA/DFAA ratios in the matrix water, however, were 5 to $9 \times$ lower than in the surrounding water except for aggregates composed of green algae of benthic origin on 9 June and of cyanobacteria in fall. Aggregates composed of molts of daphnids, large diatoms, and miscellaneous components were more enriched in DFAA than in DCAA (Table 2). In contrast, the aggregates composed of benthic green algae and of cyanobacteria were more enriched in DCAA (except on 12 October). 
Table 2. Type of aggregate, depth of sampling, DFAA and DCAA in the matrix water of aggregates and in the surrounding water. Enrichment factor is the ratio of concentrations of DFAA and DCAA in the matrix water of aggregates over those in the surrounding water

\begin{tabular}{|c|c|c|c|c|c|c|c|c|c|c|}
\hline \multirow[t]{2}{*}{ Date } & \multirow[t]{2}{*}{ Aggregate type } & \multirow{2}{*}{$\begin{array}{c}\text { Depth } \\
(\mathrm{m})\end{array}$} & \multicolumn{3}{|c|}{ Aggregate } & \multicolumn{3}{|c|}{ Surrounding water } & \multicolumn{2}{|c|}{ Enrichment factor } \\
\hline & & & $\begin{array}{l}\text { DFAA } \\
(\mu \mathrm{M})\end{array}$ & $\begin{array}{c}\text { DCAA } \\
(\mu \mathrm{M})\end{array}$ & DCAA/DFAA & $\begin{array}{l}\text { DFAA } \\
(\mu \mathrm{M})\end{array}$ & $\begin{array}{c}\text { DCAA } \\
(\mu \mathrm{M})\end{array}$ & DCAA/DFAA & DFAA & DCAA \\
\hline 2 Jun & Molts of daphnids & 15 & 0.52 & 9.8 & 18.9 & 0.05 & 5.6 & 112.0 & 10.4 & 1.8 \\
\hline 9 Jun & Green algae & 25 & 0.52 & 49.9 & 95.7 & 0.18 & 4.5 & 25.0 & 2.9 & 11.1 \\
\hline 22 Jul & Large diatoms & $\begin{array}{l}15 \\
25\end{array}$ & $\begin{array}{l}0.25 \\
0.22\end{array}$ & $\begin{array}{r}8.2 \\
18.1\end{array}$ & $\begin{array}{l}32.8 \\
82.3\end{array}$ & $\begin{array}{l}0.01 \\
0.01\end{array}$ & $\begin{array}{l}9.5 \\
5.2\end{array}$ & $\begin{array}{r}95.0 \\
520.0\end{array}$ & $\begin{array}{l}25.0 \\
22.0\end{array}$ & $\begin{array}{l}0.9 \\
3.5\end{array}$ \\
\hline $26 \mathrm{Jul}$ & Large diatoms & 15 & 0.35 & 10.3 & 29.4 & 0.02 & 5.1 & 255.0 & 17.5 & 2.0 \\
\hline $29 \mathrm{Jul}$ & Large diatoms & $\begin{array}{l}15 \\
25\end{array}$ & $\begin{array}{l}0.29 \\
0.72\end{array}$ & $\begin{array}{r}10.0 \\
5.2\end{array}$ & $\begin{array}{r}34.5 \\
7.2\end{array}$ & $\begin{array}{l}0.02 \\
0.03\end{array}$ & $\begin{array}{l}2.5 \\
2.1\end{array}$ & $\begin{array}{r}125.0 \\
70.0\end{array}$ & $\begin{array}{l}14.5 \\
24.0\end{array}$ & $\begin{array}{l}4.0 \\
2.5\end{array}$ \\
\hline 16 Aug & Large diatoms & $\begin{array}{l}15 \\
25\end{array}$ & $\begin{array}{l}0.32 \\
0.23\end{array}$ & $\begin{array}{r}12.2 \\
6.8\end{array}$ & $\begin{array}{l}38.1 \\
29.6\end{array}$ & $\begin{array}{l}0.09 \\
0.11\end{array}$ & $\begin{array}{l}5.6 \\
4.5\end{array}$ & $\begin{array}{l}62.2 \\
40.9\end{array}$ & $\begin{array}{l}3.6 \\
2.1\end{array}$ & $\begin{array}{l}2.2 \\
1.5\end{array}$ \\
\hline 26 Aug & Miscellaneous & 25 & 0.15 & 5.1 & 34.0 & 0.01 & 2.7 & 270.0 & 15.0 & 1.9 \\
\hline 4 Sep & Miscellaneous & 25 & 0.25 & 13.1 & 52.4 & 0.01 & 2.7 & 270.0 & 25.0 & 4.9 \\
\hline $16 \mathrm{Sep}$ & Cyanobacteria & 6 & 0.38 & 6.2 & 16.3 & 0.15 & 2.4 & 16.0 & 2.5 & 2.6 \\
\hline $12 \mathrm{Oct}$ & Cyanobacteria & 6 & 0.31 & 4.2 & 13.5 & 0.19 & 3.1 & 16.3 & 1.6 & 1.4 \\
\hline 13 Oct & Cyanobacteria & $\begin{array}{r}6 \\
15\end{array}$ & $\begin{array}{l}0.61 \\
0.48\end{array}$ & $\begin{array}{r}16.5 \\
2.3\end{array}$ & $\begin{array}{l}27.0 \\
25.6\end{array}$ & $\begin{array}{l}0.21 \\
0.18\end{array}$ & $\begin{array}{l}2.2 \\
2.0\end{array}$ & $\begin{array}{l}10.5 \\
11.1\end{array}$ & $\begin{array}{l}2.9 \\
2.7\end{array}$ & $\begin{array}{l}7.5 \\
6.2\end{array}$ \\
\hline
\end{tabular}
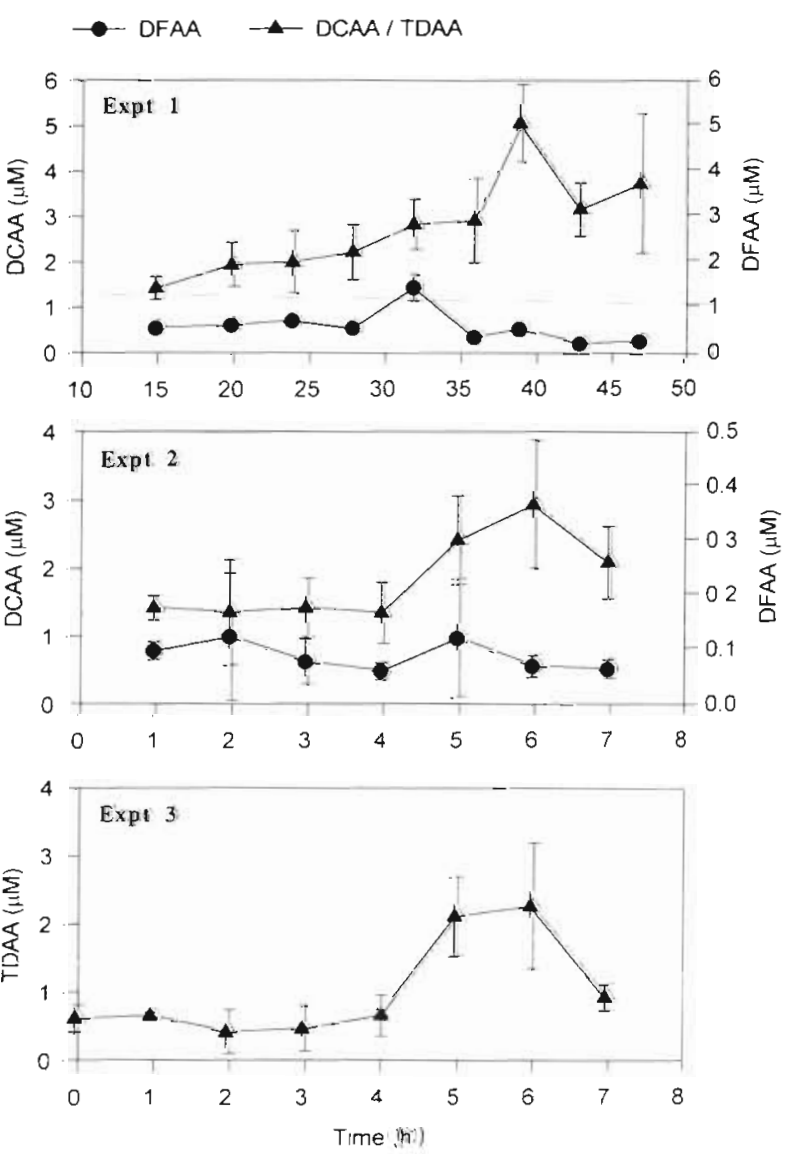

Fig. 4. Release of dissolved free (DFAA) and combined (DCAA) amino acids from lake snow $(n=10)$ collected at $15 \mathrm{~m}$ depth. Aggregates in Expts 1 to 3 were incubated at in situ temperature in rolling cylinders on 16 October 1992, 3 April and 10 April 1993, respectively. In Expt 3 only total dissolved amino acids

(TDAA) were measured. Note the different time scales

\section{Release of dissolved amino acids into the surrounding water}

Microbial processes on aggregates released dissolved amino acids into the surrounding water in all experiments (Fig. 4). Most release occurred as DCAA and little, if any, as DFAA, In Expt 1, TDAA (DFAA + DCAA) release was $3.6 \mu \mathrm{mol}$ in $24 \mathrm{~h}$, or $15 \mathrm{nmol}$ TDAA agg. $^{-1} \mathrm{~h}^{-1}$. Release rates in Expts 2 and 3 were $28 \mathrm{nmol}$ TDAA agg. ${ }^{-1} \mathrm{~h}^{-1}$. In Expt 4 using lab-made aggregates, which were $\sim 10 \times$ bigger than natural aggregates, the release rate was $82 \mathrm{nmol}$ TDAA agg. ${ }^{-1} \mathrm{~h}^{-1}$

\section{Hydrolytic enzyme activities}

The enhanced concentrations of dissolved amino acids in the matrix water and the high release rates of TDAA are consistent with high rates of aminopeptidase activity on lake snow. This activity was $<0.5$ to $21.8 \mu \mathrm{mol} \mathrm{agg.} .^{-1} \mathrm{~h}^{-1}$ (Fig. 5). Values $>2 \mu \mathrm{mol} \mathrm{agg.}{ }^{-1} \mathrm{~h}^{-1}$ occurred in June when aggregates derived from benthic algae were abundant and in October during the cyanobacterial bloom. In general, activities were highest at $15 \mathrm{~m}$ except in the cases mentioned. Excluding these numbers, which were not representative of the plankton-derived aggregates, seasonal means were $12 \pm 2 \mathrm{nmol} \mathrm{agg.} .^{-1} \mathrm{~h}^{-1}$ at $6 \mathrm{~m}, 21 \pm 3 \mathrm{nmol} \mathrm{agg.}{ }^{-1} \mathrm{~h}^{-1}$ at $15 \mathrm{~m}$, and $8 \pm 2 \mathrm{nmol} \mathrm{agg}^{-1} \mathrm{~h}^{-1}$ at $25 \mathrm{~m}$.

Aminopeptidase activity of free-living bacteria was 20 to $500 \mathrm{nmol} \mathrm{l}^{-1} \mathrm{~h}^{-1}$. In contrast to aggregate-associated aminopeptidase activity these values decreased slightly with depth. Except for the surface film and aggregates of benthic origin in June, aminopeptidase 
activities in the surrounding water were only up to $4.75 \times$ higher than on aggregates in the same volume of water, indicating that a large fraction of the potential aminopeptidase activity was due to aggregate bacteria. Cellspecific aminopeptidase activity was 0.8 to $218 \mathrm{fmol} \mathrm{cell}^{-1} \mathrm{~h}^{-1}$ on lake snow and 4 to $214 \mathrm{fmol} \mathrm{cell}^{-1} \mathrm{~h}^{-1}$ in the surrounding water (Table 3 ). Cell-specific aminopeptidase activities on aggregates were higher than in the surrounding water whenever aggregates were highly abundant and mainly composed of phytoplankton-derived material, e.g. in late April, early August, and in October.

Alkaline phosphatase (APase) activity was highly variable ( 8 to $850 \mathrm{nmol}$ agg. ${ }^{-1} \mathrm{~h}^{-1}$ ) throughout the season. As with aminopeptidase, the highest values occurred on the surface layer at the end of March and in June on aggregates derived from benthic algae (Fig. 6). Usually there was no systematic difference with depth. This is also shown by the similar seasonal means at 6,15 , and $25 \mathrm{~m}$ of $28 \pm 4,27 \pm 3$, and $21 \pm 3$ nmol agg, ${ }^{-1} \mathrm{~h}^{-1}$, respectively. APase activities in $1 \mathrm{l}$ of surrounding water ranged between 15 and $115 \mathrm{nmol} \mathrm{l}^{-1}$ $\mathrm{h}^{-1}$, with a pronounced maximum during the spring bloom. Thereafter rates never exceeded $50 \mathrm{nmol} \mathrm{l}^{-1}$ $\mathrm{h}^{-1}$. Only during the spring was there a systematic decrease of APase activities with depth, whereas at other times rates from 6 to $25 \mathrm{~m}$ were fairly similar. In contrast to total activities of APase, the cell-specific activities of aggregate bacteria were up to $14.8 \times$ higher than those of free-living ones.

$\beta$-Glucosidase activity on lake snow was 2 to $72 \mathrm{nmol}$ agg. ${ }^{-1} \mathrm{~h}^{-1}$, excluding the surface film at the end of March (Fig. 7). Excluding the highest rates on benthic aggregates in June, rates did not exceed $50 \mathrm{nmol}$ agg. ${ }^{-1} h^{-1}$. There was no systematic difference of rates between 6 and $25 \mathrm{~m}$. Rates of $\beta$-glucosidase in the surrounding water were 7 to $21 \mathrm{nmol}^{-1} \mathrm{~h}^{-1}$ without any pronounced differences in space or time (not shown). Cell-specific activities of $\beta$-glucosidase of lake-snowassociated bacteria were $\leq 13 \times$ higher than of freeliving ones.

$\alpha$-Glucosidase activity was in general lower but exhibited similar spatio-seasonal pattern (not shown). Rates and spatio-seasonal pattern of $\mathrm{N}$-acetyl $\beta$-glucosidase, which cleaves the dimeric hydrolysis product of the chitinase, were also nearly similar to those of $\beta$ glucosidase (not shown).

Activities of aminopeptidase, APase, $\alpha$ - and $\beta$-glucosidase on the diatom surface film in late March were in the highest range measured on aggregates throughout the season. Rates of $\alpha$-and $\beta$-glucosidase were even 3 to $4 \times$ higher than on any other type of aggregate

\section{Turnover of particulate combined amino acids (PCAA)}

PCCA turnover times on aggregates were calculated from the PCAA content and the aminopeptidase

Table 3. Hydrolytic ectoenzyme activities on lake snow aggregates and in the surrounding water

\begin{tabular}{|c|c|c|c|c|c|}
\hline \multirow{2}{*}{ Enzyme } & \multicolumn{2}{|c|}{ Hydrolytic activities } & \multicolumn{3}{|c|}{ Cell-specific activities } \\
\hline & $\begin{array}{r}\text { Aggregate } \\
\text { ( } \mu \mathrm{mo}\end{array}$ & $\begin{array}{l}\text { Surrounding water } \\
\left.\mathrm{l}^{-1} \mathrm{~h}^{-1}\right)\end{array}$ & $\begin{array}{r}\text { Aggregate } \\
\text { (fmo }\end{array}$ & $\begin{array}{l}\text { Surrounding water } \\
\left(\text { cell }^{-1} \mathrm{~h}^{-1}\right)\end{array}$ & Aggregate/surrounding water \\
\hline Aminopeptidase & $0.002-218^{\mathrm{a}}$ & $0.02-0.5$ & $0.8-218$ & $4-214$ & $0.2-46.1$ \\
\hline Phosphatase & $0.005-8.2$ & $0.015-0.115$ & $0.3-57$ & $0.6-35$ & $0.5-14.8$ \\
\hline$\beta$-Glucosidase & $0.001-0.7^{\mathrm{a}}$ & $0.007-0.021$ & $0.08-2.21$ & $0.12-2.04$ & $0.2-13.3$ \\
\hline
\end{tabular}




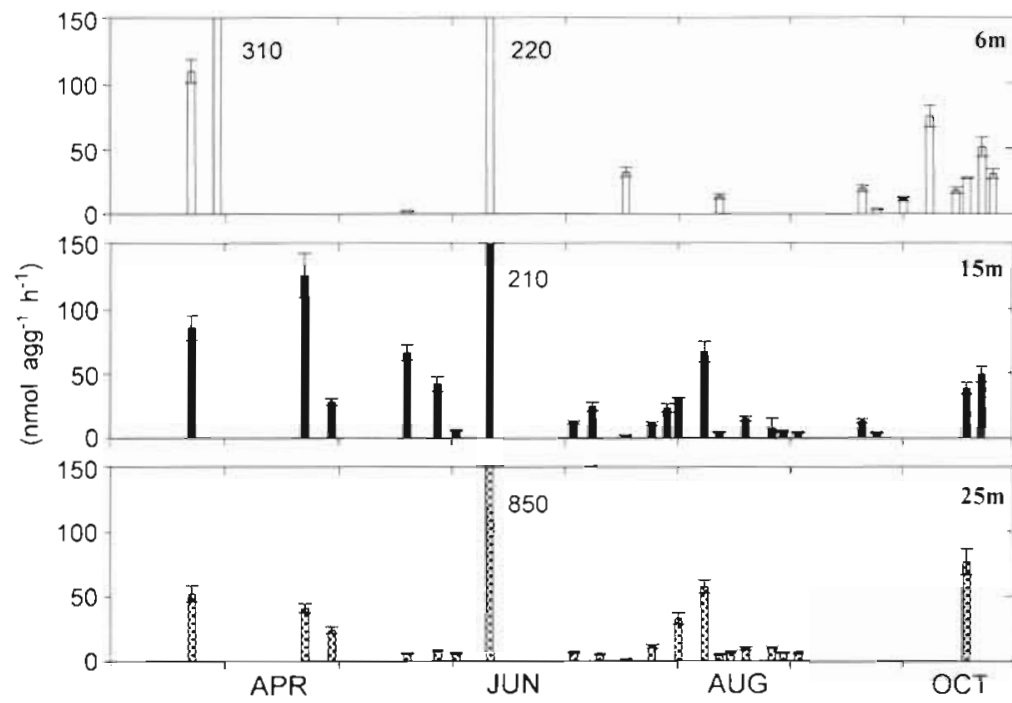

Fig. 6. Activities of alkaline phosphatase (APase) on lake snow at 6, 15, and $25 \mathrm{~m}$ depth in Lake Constance in 1993
PCAA turnover on lake snow was further calculated from the BPP-C on aggregates, assuming a bacterial growth efficiency of $30 \%$. The PCAA turnover times thus obtained were significantly higher than those calculated from aminopeptidase activity and net release of amino acids and showed high seasonal fluctuations (5 to 227 d). Like for the PCAA turnover calculated by aminopeptidase activities, those by BPP-C were extremely slow on resuspended aggregates (728 d). The fact that PCAA turnover times on lake snow calculated on the basis of carbon consumption were far higher than those calculated on the basis of amino acid release indicates that the latter process was of much higher significance for the amino acid turnover on aggregates. activity on lake snow. Since the incubated saturating concentration of the artificial substrate was much higher than the natural concentration of PCAA on aggregates, we used the ratio between the concentration of the artifical and natural substrate to correct for the measured maximum rates. Turnover times of PCAA on aggregates due to their aminopeptidase activity were mostly fairly short $(0.04$ and $381 \mathrm{~h}$; Fig. 8). Very high aminopeptidase activity enhanced the PCAA turnover of the diatom surface film in spring and that of large green algae in early June. In contrast, aminopeptidase activity of resuspended sediment material in September was low and resulted in prolonged PCAA turnover times. During the whole season the PCAA turnover on organic aggregates due to their aminopeptidase activity was $<20 \mathrm{~h}$ at all depths.

PCAA turnover times calculated from the net release of dissolved amino acids into the surrounding water were probably underestimates because the utilization of released amino acids by aggregates and also free-living bacteria is neglected. However, this method gave PCAA turnover rates somewhat higher than calculated by the aminopeptidase activity. Interestingly, PCAA turnover times on aggregates in Expts 2 and 3 (3 and 10 April 1993) were very similar (89.3 and 79.2 h.), whereas aggregates in Expt 1 (October 1992) showed a reduced PCAA turnover (154.8 h) and also a lower aminopeptidase activity.

\section{Bacterial colonization of aggregates}

Colonization of lab-made aggregates incubated in rolling cylinders showed a recurrent pattern in all experiments. During the first $2 d,<1 \mu \mathrm{m}$ cocci were dominant (Fig. 9). Bacterial community structure shifted to rods when larger aggregates were formed. Bacteria were enlarged and formed large colonies after 2 to $3 \mathrm{~d}$ when Spumella-type flagellates occurred. Filamentous or flagellated bacteria dominated after 5 to $7 \mathrm{~d}$ when Spumella-type flagellates reached highest abundances. After $9 \mathrm{~d}$ Kinetoplastid-type flagellates
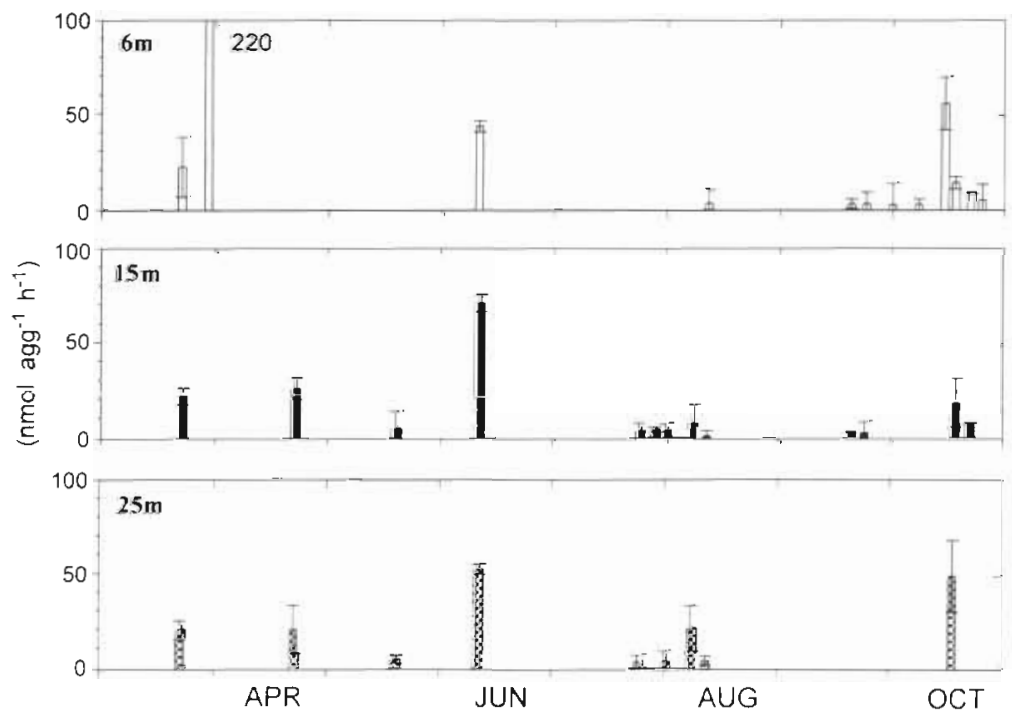

Fig. 7. Activities of $\beta$-glucosidase on lake snow at 6,15 , and $25 \mathrm{~m}$ depth in Lake Constance in 1993 
appeared which later completely outcompeted Spumella-type flagellates.

We analyzed the structure of the microbial assemblage on aggregates by in situ hybridization with rRNAtargeted oligonucleotide probes. Bacterial counts by DAPI staining were 1 to $13 \times 10^{6}$ agg $^{-1}$ (Fig. 10). Bacteria detected with the probe EUB 338 yielded 55 to $100 \%$ of total cell numbers. $\alpha-, \beta-$, and $\gamma$-subclass Proteobacteria were usually the dominant bacterial subclasses (>30\%; generally $>70 \%$ of total). $\beta$-Proteobacteria dominated all experiments except Expt 3 and $\alpha$ - and $\gamma$-Proteobacteria were less abundant. In contrast, $\gamma$ Proteobacteria dominated during Expt 3 and comprised $>75 \%$ of total cells after $6 \mathrm{~d}$. This experiment was run at $15^{\circ} \mathrm{C}$ instead of the in situ temperature $\left(4^{\circ} \mathrm{C}\right)$.

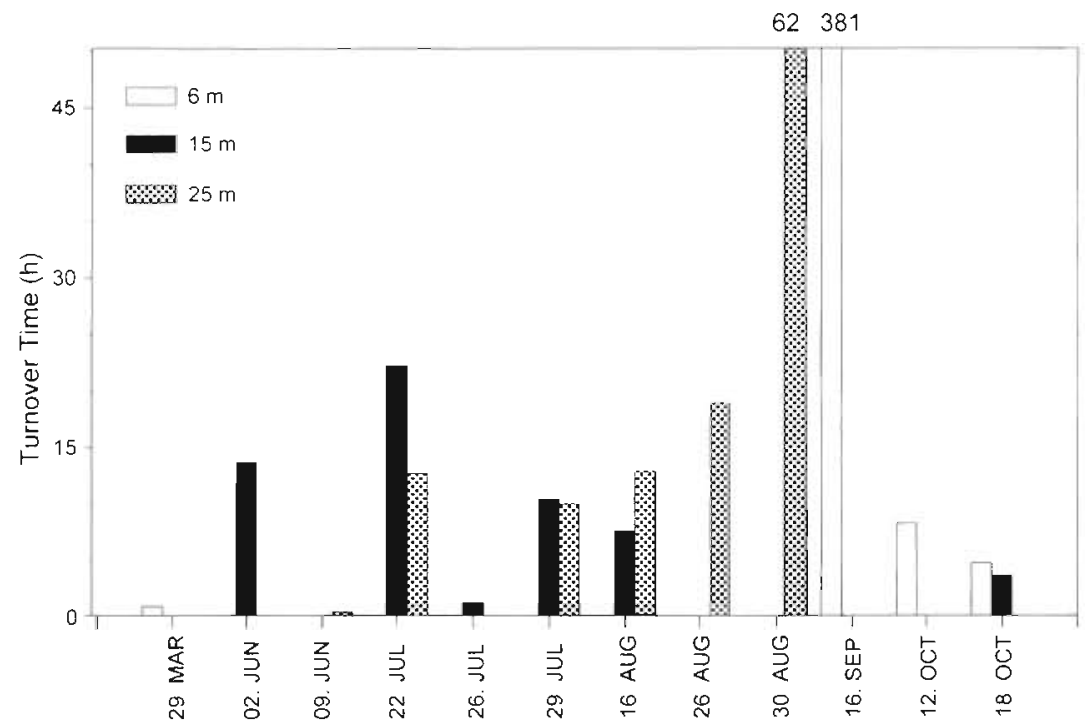

Fig. 8. Turnover time of particulate combined amino acids (PCAA) on lake snow on the basis of aminopeptidase activity. Values were calculated from PCAA content and total aminopeptidase activity on aggregates at 6,15 , and $25 \mathrm{~m}$ depth

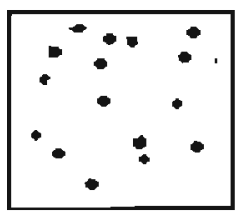

Day 1: microaggregates $(<3 \mathrm{~mm} \varnothing)$ : fragments of diatoms,

bacteria: small cocci $(<1 \mu \mathrm{m} \varnothing)$

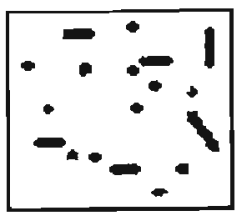

Day 2: microaggregates $(<3 \mathrm{~mm} \varnothing)$ : detritus and living algae,

bacteria: mostly small cocci $(<1 \mu \mathrm{m} \varnothing)$ and short but thick rods

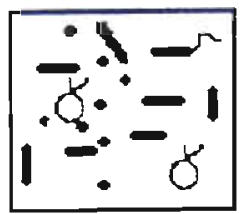

Day 3: aggregates ( $<5 \mathrm{~mm} \varnothing$ ): detritus and living algae.

bacteria: mostly short but thick rods, few flagellated forms, few flagellates of the Spumella type

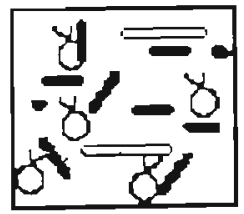

Day 4: aggregates $(<5 \mathrm{~mm} \varnothing)$ ) detritus and living algae,

bacteria: mostly short but thick rods, few long rods, increasing number of flagellates of the Spumella type

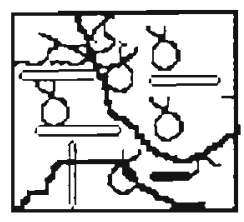

Day 5: aggregates $(<9 \mathrm{~mm} \varnothing)$ : detritus and living algae,

bacteria: mostly long rods, few flagellated and colony-forming rods, increasing number of flagellates of the Spumella type

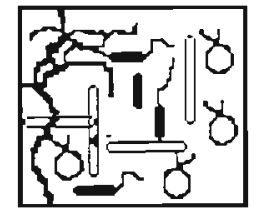

Days $6+7$ : aggregates $(=9 \mathrm{~mm} \varnothing)$ : detritus and living algae,

bacteria: mostly long rods, few flagellated and colony-forming rods, high numbers of flagellates of the Spumella type

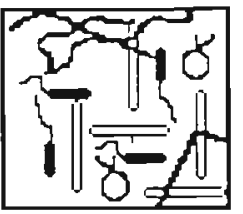

Day 8: aggregates (>9 $\mathrm{mm} \varnothing)$ : detritus and living algae, only filamentous and flagellated bacteria (Caulobacter), maximum of flagellates of the Spumella type

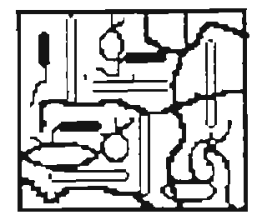

Days 9-11. aggregates (>9 $\mathrm{mm} \varnothing)$ : detritus and living algae,

bacteria: long and thick rods, mostly flagellated, Spumella-and few of the Kinetoplastid-type flagellates

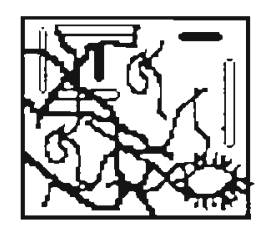

Day 12: aggregates ( $>9 \mathrm{~mm} \varnothing$ ): detritus and living algae, dense colonization by colony-forming bacteria, few small rods, mostly flagellates of the Kinetoplastid type

Fig. 9. Sequence of formation of aggregates and their microbial colonization during incubation of natural lake water in rolling cylinders 


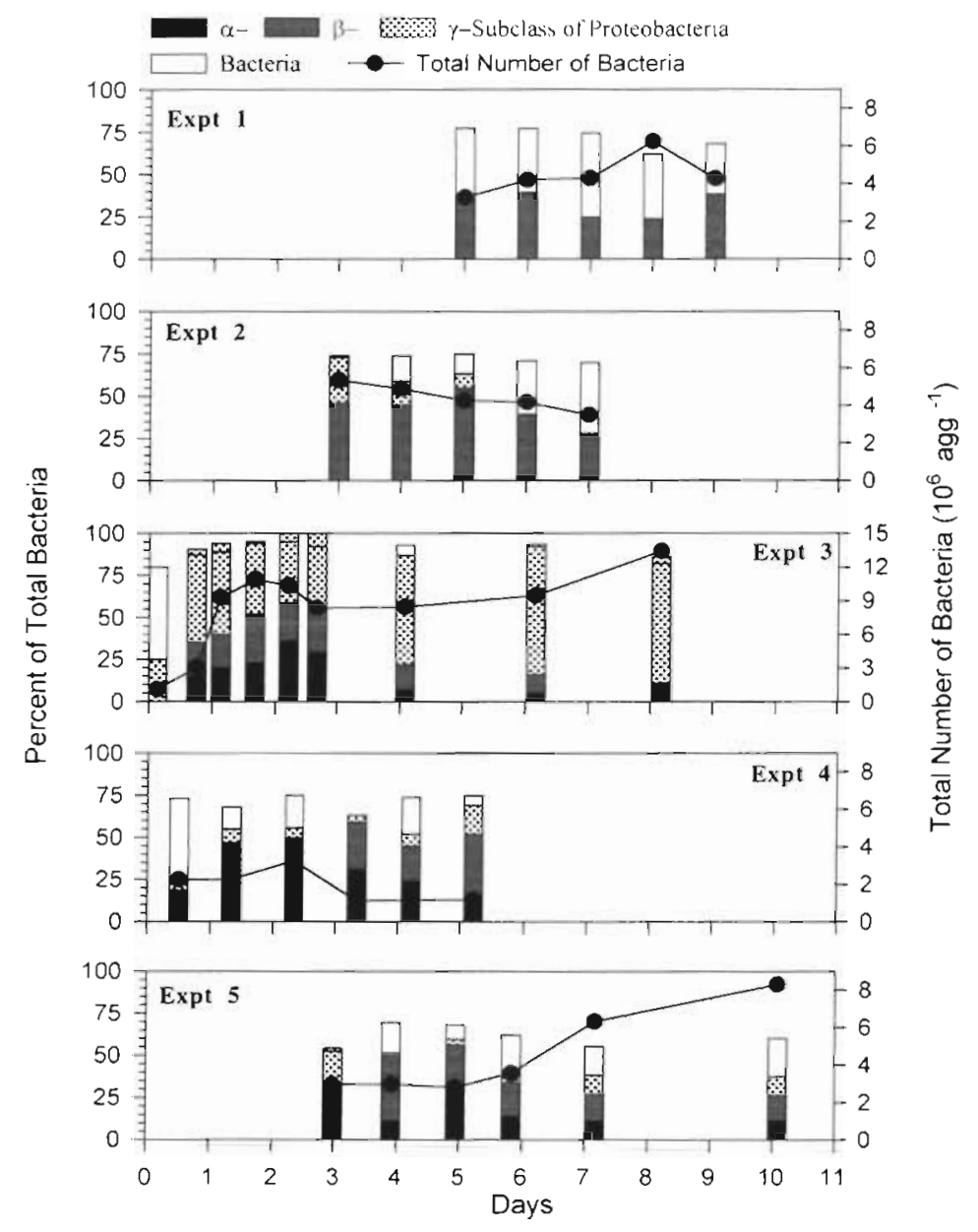

Fig. 10. Succession of Bacteria and Proteobacteria of the $\alpha_{-}, \beta-$, and $\gamma$ subclasses as percentage of total bacteria on natural lake snow incubated in rolling cylinders at various times

\section{DISCUSSION}

\section{Bacterial production and growth rates}

Bacterial production and growth rates on aggregates were quite low despite high bacterial numbers and rapid POM solubilization, indicating loose hydrolysisuptake coupling. However, the bacterial production and growth rates could have been underestimated due to extracellular and intracellular isotope dilution (ID) of ${ }^{14} \mathrm{C}$-leucine. DFAA concentrations in the matrix water were much higher than in the surrounding water (Table 2). Since we achieved maximum rate of incorporation at $60 \mathrm{nM}$ added ${ }^{14} \mathrm{C}$-leucine, the extracellular leucine ID may have been overcome by this high addition. We could not determine the intracellular ID, so we cannot rule out that the ID of 2 we used may have been too low or too high. Azam et al. (1993), using in vitro experimental systems, showed that bacterial growth rates in the initial phase of colonization were high but slowed in later stages during the establishment of an aggregate-associated bacterial community. Further, a cross-system overview (Alldredge \& Gotschalk 1990) showed that thymidine incorporation per bacterium decreased significantly with increasing abundance of bacteria per $\mu \mathrm{g}$ dry weight on aggregates. We assume, however, that the low values of BPP-C and bacterial growth rates we found were not biased substantially but reflect the fact that bacterial growth on aggregates at least 2 to $3 \mathrm{~d}$ old is indeed low.

\section{Release of dissolved amino acids}

The release of amino acids from lake snow into the surrounding water was high whereas bacterial production was low. This suggests that protein hydrolysis and hydrolysate utilization by aggregate bacteria are loosely coupled, leading to release of dissolved amino acids into the surrounding water (Smith et al. 1992). Further, in our experiments, this release was not always continuous but occurred in pulses. DFAA and DCAA concentrations in the matrix water were much higher than in the surrounding water. The enrichment factor for DFAA was generally higher than for DCAA (Table 2). Only for the very large benthic aggregates in June and cyanobacterial aggregates in the fall was the enrichment factor for DCAA at least as high as for DFAA. The high DFAA enrichment in the matrix water and their fairly low net release into the surrounding water (see below) suggest that the recycling of amino acids within the aggregates occurred predominantly via DFAA. There is no other information on the relative utilization of DFAA and DCAA within aggregates. Müller-Niklas et al. (1994), however, also showed that marine snow is highly enriched in DFAA relative to the surrounding water.

\section{Hydrolytic enzyme activities}

Ectoenzyme activities also suggested rapid POM and dissolved polymer hydrolysis within the aggregates Aminopeptidase activity on lake snow was always higher than APase, $\alpha$ - and $\beta$-glucosidase, and chitinase activities. Müller-Niklas et al. (1994) and Smith et al. $(1992,1995)$ also found that aminopeptidase on marine 
snow was generally much higher than $\alpha$ - and $\beta$-glucosidase. However, measuring hydrolytic enzyme activities with substrate analogs yields maximum hydrolysis potential. Rosenstock \& Simon (1993) showed that potential rates of DCAA utilization by bacteria are 3 to $10 \times$ higher than the actual rates. Taking into account the fact that proteins comprise $<10 \%$ of DCAA (Keil \& Kirchman 1993, B. Rosenstock unpubl.), ambient utilization rates of proteins per cell are even lower. Hence, we hypothesize that at the ambient DCAA and protein concentrations in the bulk water, their hydrolysis rates are not saturated, whereas they are saturated at higher substrate concentrations such as in PCAA rich microenvironments of lysing algae and lake snow. In contrast, cell-specific utilization of dissolved polysaccharides at ambient concentrations have been shown to be in the same range as potential rates of $\beta$ glucosidase measured at saturating concentrations of the fluorogenic substrate (Hanisch et al. 1996). Thus, higher concentrations of dissolved polysaccharides on aggregates cannot yield enhanced rates of $\beta$-glucosidase activity. Differences in potential and ambient hydrolysis rates may explain why potential rates of aminopeptidase are always higher than that of glucosidases, not only on aggregates but also in the bulk water (Chróst 1991). Thus, bacteria are able to readily hydrolyze and utilize DCAA and dissolved proteins at enhanced concentrations such as in the microenvironment of aggregates.

\section{PCAA turnover}

PCAA turnover calculated by aminopeptidase hydrolysis or net release of dissolved amino acids on lake snow was rapid. These calculations are based on the assumption that the DCAA concentration in the matrix water is equal to the ambient aminopeptidase substrate concentration. However, a certain fraction of the DCAA pool can be resistant to bacterial hydrolysis and utilization. Labile proteins as well as peptides comprise only a minor fraction of total DCAA which is in the bulk water, usually 10 to $20 \%$ (Keil \& Kirchman 1993 , Rosenstock \& Simon 1993). On the other hand, DCAA in the matrix water of lake snow are of relatively fresh origin and may have higher concentrations of labile proteins and peptides than bulk DCAA. Although we may have underestimated the PCAA turnover on aggregates, we yielded much shorter and more realistic turnover times than calculated by bacterial production and a growth efficiency of $30 \%$. PCAA turnover times calculated by aminopeptidase acitivity were further confirmed by the fact that PCAA turnover times calculated from the net release of dissolved amino acids were similar.
In addition to amino acid turnover it is also important to estimate the significance of the DCAA release on aggregates for the turnover of bulk DCAA. For this we assumed an abundance of 2 to $10 \mathrm{agg} . \mathrm{1}^{-1}$, a release rate of 15 to $28 \mathrm{nmol}$ DCAA agg. ${ }^{-1} \mathrm{~h}^{-1}$, and a concentration of bulk DCAA of 2 to $5 \mu \mathrm{M}$ (Rosenstock \& Simon 1993). On this basis the turnover time of bulk DCAA is 40 to $160 \mathrm{~h}$ and similar to measured turnover times of bulk DCAA in Lake Constance (Rosenstock \& Simon 1993). Turnover times of dissolved proteins in Lake Constance are even faster (B. Rosenstock unpubl.). Our calculation shows that DCAA release from lake snow into the surrounding water could be important for supplying free-living bacteria with DCAA in the epi- and hypolimnion. However, DCAA release from aggregates is not always a continuous process and sinking aggregates may even scavenge DCAA in the hypolimnion (Grossart \& Simon 1998).

\section{Changes in aggregate composition during aging and sinking}

Release of dissolved amino acids leads to a depletion of particulate organic nitrogen (PON) from aging aggregates. This is reflected by the decreasing PCAA fraction relative to POC from lake snow to POM collected in 50 m sediment traps (Grossart \& Simon 1998) and by the higher depletion of PON relative to $P$ and dry weight of sediment trap material (Gries 1995). In addition, the PCAA turnover of sediment material from $50 \mathrm{~m}$ calculated by DCAA net release was 6.9 to $54.5 \mathrm{~d}$ (Grossart \& Simon 1998) and thus much longer than that of lake snow. Even though sinking aggregates become depleted of PCAA and PON in lakes, they still comprise fairly high amounts of PON when reaching the lake sediment. The short sinking distance in most lakes $(\leq 100$ to $200 \mathrm{~m}$ ) results in an aggregate age of 5 to $15 \mathrm{~d}$. In contrast, sinking aggregates in the ocean become much more depleted in PON and show increased $\mathrm{C}: \mathrm{N}$ ratios with depth due to the longer sinking distance loften $>1000 \mathrm{~m}$; Wakeham et al. 1984, Lee 1988, Haake et al. 1993, Wakeham \& Lee 1993).

\section{Bacterial colonization during aging and sinking of lake snow}

During aging and sinking of lake snow, its microbial community showed changes in morphology and taxonomy which presumably reflect the biochemical composition and the DOM release of the aggregates. Characteristic changes in the microbial community structures were observed during the incubation of lab-made aggregates and also by comparing lake snow with 
sediment trap material which consisted of older aggregated material. Bacterial community structure after 1 to 4 d incubation of aggregates presumably reflected more the composition of lake snow in the epilimnion and upper hypolimnion. In later stages the co-occurrence of filamentous bacteria and flagellates presumably reflected structural adaptations of aggregate bacteria to higher grazing pressure by flagellates (Güde 1979, Jürgens \& Güde 1994). These authors observed that mixed bacterial assemblages in various environments adapted to flagellate grazing by forming filamentous and thus grazing-resistant forms. Even though lab-made aggregates became larger after 6 to 7 d than natural lake snow, Weiss et al. (1996) showed that the bacterial community structure of these aggregates was not different after $13 \mathrm{~d}$ from that on lake snow and sediment trap material. However, when aggregates reach the sediment with different environmentaJ conditions than the water column their community structure may undergo pronounced changes.

rRNA-targeted oligonucleotide probes indicated that the majority of the bacteria on lake snow belonged to the domain Bacteria. The remaining fraction not accounted for presumably also consisted of Bacteria with numbers of ribosomes too low to be detected with this probe. Neither we nor Weiss et al. (1996) ever detected Archaea. $\beta$-Proteobacteria were dominant whereas $\gamma$ Proteobacteria were of minor importance except in Expt 3. $\alpha$-Proteobacteria constituted sometimes substantial proportions of the bacterial community, mainly in the earlier stages of the incubation. These results agree well with those of Weiss et al. (1996), who found a similar dominance of $\beta$-Proteobacteria on lake snow in Lake Constance. They also found that, on younger lab-made and natural aggregates, $\alpha$-Proteobacteria often comprise high proportions, whereas on older aggregates and on sediment trap material $\beta$-Proteobacteria become more dominant. Interestingly, on activated sludge flocs, $\beta$-Proteobacteria dominate the bacterial community (Wagner et al. 1994), and microbes closely related to bacteria such as Zoogloea ramigera and Sphaerotilus natans are often filamentous and most frequent. Hence these observations suggest that lake snow harbors a microbial community closely related to that of activated sludge flocs and that it is characterized by a rapid recycling and release of labile DOM.

Pernthaler et al. (1997) observed in a 2-stage chemostat that flagellate grazing is the driving force forming filamentous bacteria and a community dominated by $\beta$-Proteobacteria. Flagellates selectively fed on $\alpha$ Proteobacteria which had high growth rates and were always present as a minor fraction of total bacteria. If this is also true for microbial communities on lake snow, $\alpha$-Proteobacteria would mediate the recycling of
DOM and substrates within the aggregates. Their growth rates would be more important in early aggregate history. In contrast, filamentous $\beta$-Proteobacteria on lake snow would have lower growth rates but higher hydrolytic enzyme activities and the dominance of $\beta$-Proteobacteria could be regarded as an indication of the presence of bacterivorous flagellates and possibly ciliates in later stages.

In Expt 3, run at $15^{\circ} \mathrm{C}$ instead of $4^{\circ} \mathrm{C}, \gamma$-Proteobacteria became dominant which mainly utilize readily available organic compounds (Wagner et al. 1993). Thus, temperature may be an additional important factor controlling bacterial community structure. However, further experiments need to examine more carefully the influence of temperature on bacterial community structure on aggregates and in the surrounding water.

\section{Conclusions}

Our results show that lake snow aggregates act as hotspots of enhanced microbial POM decomposition and thus constitute an important source of dissolved organic matter in the epi- and hypolimnion of Lake Constance. The microbial community on lake snow was dominated by $\beta$-Proteobacteria, especially during aggregate aging when filamentous and thus grazingresistant bacteria dominated. This community structure is similar to that of activated sludge flocs. These observations suggest that lake snow and activated sludge flocs have similar functions in their environment.

Acknowledgements. We thank T Gries, M. Decker, and $H$. Wiedemann for their invaluable help on board ship for sampling and B. Rosenstock for services with the analyses of amino acids by HPLC. This work was carried out as part of the Special. Collaborative Programm SFB 248 'Cycling of Matter in Lake Constance (Bodensee)' funded by Deutsche Forschungsgemeinschaft.

\section{LITERATURE CITED}

Alldredge AL, Cohen Y (1987) Can microscale chemical patches persist in the sea? Microelectrode study of marine snow, fecal pellets. Science 235:589 591

Alldredge AL, Gotschalk CC (1990) The relative contribution of marine snow of different origins to biological processes in coastal waters. Cont Shelf Res 10:41-58

Alldredge AL, Silver MW (1988) Characteristics, dynamics and significance of marine snow. Prog Oceanogr 20:41-82

Amann RI, Binder BJ, Olson RI, Christholm SW, Devereux R, Stahl DA (1990) Combination of $16 \mathrm{~S}$ rRNA-targeted oligonucleotide probes with flow cytometry for analysing mixed microbial populations. Appl Environ Microbiol 56: 1919-1925

Azam F, Martinez J, Smith DC (1993) Bacteria-organic matter coupling on marine aggregates. In: Guerrero $R$, Pedrós- 
Alió C (eds) Trends in microbial ecology. Spanish Society for Microbiology, Barcelona, p 410-414

Bianchi M, Marty D. Teyssié JL, Fowler SW (1992) Strictly aerobic and anaerobic bacteria associated with sinking particulate matter and zooplankton fecal pellets. Mar Ecol Prog Ser 88:55-60

Caron DA, Davis PG, Madis LP, Sieburth JMCN (1986) Enrichment of microbial populations in macroaggregates (marine snow) from surface waters of the North Atlantic. J Mar Res 44:543-565

Chin-Leo G, Kirchman DL (1988) Estimating bacterial production in marine waters from the simultaneous incorporation of thymidine and leucine. Appl Environ Microbiol 54: $1934-1939$

Cho BC, Azam F (1988) Major role of bacteria in biogeochemical fluxes in the ocean's interior. Nature 332:441-443

Chróst RJ (1991) Environmental control of the synthesis and activity of aquatic microbial enzymes. In: Chróst RJ (ed) Microbial enzymes in aquatic environments. Springer Verlag, New York, p 29-59

DeLong EF, Franks DG, Alldredge AL (1993) Phylogenetic diversity of aggregate-attached vs. free-living marine bacterial assemblages. Limnol Oceanogr 38:924-934

Fuhrman JA, Azam F (1980) Bacterioplankton secondary production estimates for coastal waters of British Columbia, Antarctica and California. Appl Environ Microbiol 39 1085-1095

Gotschalk CC, Alldredge AL (1989) Enhanced primary production and nutrient regeneration within aggregated marine diatoms. Mar Biol 103:119-129

Gries T (1995) Phosphorus budget of the upper $20 \mathrm{~m}$ of Überlinger See (Lake Constance) with a special emphasis on sedimentation. PhD thesis, University of Constance (in German)

Grossart HP, Simon M (1993) Limnetic macroscopic organic aggregates (lake snow): occurrence, characteristıcs, and microbial dynamics in Lake Constance. Limnol Oceanogr 38:532-546

Grossart HP, Simon M (1998) Significance of limnetic organic aggregates (lake snow) for the sinking flux of particulate organic mäter in a large lake. Aquat Microb Ecol 15: $115-125$

Grossart HP, Simon M, Logan B (1997) Formation of macroscopic organic aggregates (lake snow) in a large lake: the significance of transparent exopolymer particles (TEP), phyto-, and zooplankton. Limnol Oceanogr 42:1651-1659

Güde H (1979) Grazing by protozoa as selection factor for activated sludge bacteria. Microb Ecol 5:225-237

Haake B. Ittekkot V, Honjo S, Manganini S (1993) Amino acid, hexosamine and carbohydrate fluxes to the deep Subarctic Pacific (Station P). Deep Sea Res 40:547-560

Hanisch K, Schweitzer B, Simon M (1996) Use of dissolved carbohydrates by planktonic bacteria in a mesotrophic lake. Microb Ecol 31:41-55

Herndl GJ (1992) Marine snow in the Northern Adriatic Sea possible causes and consequences for a shallow ecosystem. Mar Microb Food Webs 6:149-172

Hoppe HG (1991) Microbial extracellular enzyme activity: a new key parameter in aquatic ecology. In: Chróst RJ (ed) Microbial enzymes in aquatic environments. Springer Verlag, New York, p 60-83

Hoppe HG (1993) Use of fluorogenic model substrates for extracellular enzyme activity (EEA) measurements of bacteria. In: Kemp PF, Sherr BF, Sherr EB, Cole JJ (eds) Handbook of methods in aquatic microbial ecology. Lewis Publishers, Boca Raton, p 423-432

Jürgens K, Güde H (1994) The potential importance of graz- ing-resistant bacteria in planktonic systems. Mar Ecol Prog Ser 112:169-188

Kaltenböck E, Herndl GJ (1992) Ecology of amorphous aggregations (marine snow) in the Northern Adriatic Sea. IV Dissolved nutrients and the autotrophic community associated with marine snow. Nar Ecol Prog Ser 87:147-159

Keil RG, Kirchman DL (1993) Dissolved combined amino acids: chemical form and utilization by marine bacteria Limnol Oceanogr 38:1256-1270

Kirchman DL, K'Nees E, Hodson R (1985) Leucine incorporation and its potential as a measure of protein synthesis by bacteria in natural aquatic systems. Appl Environ Microbiol 49:599-607

Lee C (1988) Amino acid and amine biogeochemistry in marine particulate material and sediments. In: Blackburn $\mathrm{TH}$, Sorensen $\mathrm{J}$ (eds) Nitogen cycling in coastal marine environments. J Wiley \& Sons L.td, New York, p 125-141

Manz W, Amann RI, Ludwig W, Wagner M, Schleifer KH (1992) Phylogenetic oligonucleotide probes for the major subclasses of Proteobacteria: problems and solutions. Syst Appl Microbiol 15:593-600

Müller-Niklas G, Schuster S, Kaltenböck E, Herndl GJ (1994) Organic content and bacterial metabolism in amorphous aggregations of the Northern Adriatic Sea. Limnol Oceanogr 39:58-68

Paerl HW (1974) Bacterial uptake of dissolved organic matter in relation to detrital aggregation in marine and freshwater systems. Limnol Oceanogr 19:966-969

Paerl HW, Prufert LE (1987) Oxygen-poor microzones as potential sites of microbial $\mathrm{N}_{2}$ fixation in nitrogen-depleted aerobic marine waters. Appl Environ Microbiol 53: 1078-1087

Pernthaler J, Posch $T$, Simek K, Vrba J, Amann R, Psenner R (1997) Contrasting bacterial strategies to coexist with a flagellate predator in an experimental microbial assemblage. Appl Environ Microbiol 63:596-601

Porter KG, Feig YS (1980) The use of DAPI for identifying and counting aquatic microflora. Limnol Oceanogr 25:943-948

Rosenstock B, Simon M (1993) Use of dissolved combined and free amino acids by planktonic bacteria in Lake Constance. Limnol Oceanogr 38:1521-1531

Schaule G, Flemming HC, Ridgway HF (1993) Use of 5cyano-2,3-ditolyl tetrazolium chloride (CTC) for quantifying planktonic and sessile respiring bacteria in drinking water. Appl Environ Microbiol 59:3850-3857

Shanks AL, Edmondson EW (1989) Laboratory-made artificial marine snow: a biological model of the real thing. Mar Biol $101: 463-470$

Shanks AL, Reeder ML (1993) Reducing microzones and sulfide production in marine snow. Mar Ecol Prog Ser 96: $43-47$

Shanks AL, Trent D (1979) Marine snow: microscale nutrient patches. Limnol Oceanogr 24:850-854

Simon $M$ (1987) Biomass and production of small and large free-living and attached bacteria in Lake Constance. Limnol Oceanogr 32:591-607

Simon M. Azam F (1989) Protein content and protein synthesis rates of planktonic marine bacteria. Mar Ecol Prog Ser 65:205-211

Simon M, Rosenstock B (1992) Carbon and nitrogen sources of planktonic bacteria in Lake Constance studied by the composition and isotope dilution of intracellular amino acids. Limnol Oceanogr 37:1496-1511

Smith DC, Simon M, Alldredge AL, Azam F (1992) Intense hydrolytic enzyme activity on marine aggregates and its implications for rapid particle dissolution. Nature 359 : $139-142$ 
Smith DC, Steward GF, Long RA, Azam F (1995) Bacterial mediation of carbon fluxes during a diatom bloom in a mesocosm. Deep Sea Res 42:75-97

Wagner M, Amann RI, Kämpfer P, Assmus B, Hartmann A, Hutzler P, Springer N, Schleifer KH (1994) Identification and in situ detection of gram-negative filamentous bacteria in activated sludge. Appl Environ Microb 17: $405-417$

Wagner M, Amann RI, Lemmer H, Schleifer KH (1993) Probing activated sludge with oligonucleotides specific for proteobacteria: inadequacy of culture-dependent methods for describing microbial community structure. Appl Environ Microbiol 59:1520-1525

Editorial responsibility: Farooq Azam,

La Jolla, California, USA
Wakeham SG, Lee C (1993) Production, transport and alteration of particulate organic matter in the marine water column. In: Engle MA, Macko SA (eds) Organic geochemistry: principles and applications. Plenum, New York, p 145-169

Wakeham SG, Lee C. Farrington JW, Gagosian RB (1984) Biochemistry of particulate organic matter in the oceans results from sediment trap experiments. Deep Sea Res 31 $509-528$

Weiss P, Schweitzer B, Amann RI, Simon M (1996) Identification in situ and dynamics of bacteria on limnetic organic aggregates (lake snow). Appl Environ Microbiol 62: $1998-2005$

Submitted: July 10, 1997; Accepted: March 27, 1998

Proofs received from author(s): June 18, 1998 